АРШИН Константин Валерьевич - кандидат философских наук, Финансовый университет при Правительстве РФ (125993, Россия, г. Москва, ГСП-3, Ленинградский пр-кт, 49; kosta-10@ yandex.ru)

\title{
ДИАЛЕКТИКА СЕКЬЮРИТИЗАЦИИ И ЛИБЕРАЛИЗАЦИИ В МИГРАЦИОННОЙ ПОЛИТИКЕ РОССИИ
}

Аннотация. В статье рассматривается взаимовлияние двух тенденций в миграционной политике Российской Федерации - секьюритизации и либерализации. Автор прослеживает, как указанные тенденции находили свое отражение в управленческих решениях в миграционной сфере страны и нормативных правовых актах. По итогам проведенного анализа автор формулирует вывод, что в современной миграционной политике страны доминирует тенденция секьюритизации.

Ключевые слова: секьюритизация, либерализация, миграция, трудовая миграция, модель миграции

$\mathrm{M}$ играция - это социальный феномен, который характеризует состояние современного миропорядка. Несмотря на то что стремление к миграции изначально присуще человеку и не раз наблюдалось за долгую историю человечества, беспрецедентность масштабов современных миграционных потоков поражает. По оценке Международной организации по миграции, в 2017 г. число международных мигрантов достигло 244 млн чел., из них более 22 млн - беженцы ${ }^{1}$. Подобные масштабы перемещений ставят перед современными государствами вопрос о разработке эффективных моделей регулирования миграционных процессов. В настоящее время в мире приняты четыре модели.

1. Экономическая. Сторонники данного подхода оценивают миграционные потоки с точки зрения их выгоды и издержек для стран-реципиентов и страндоноров миграционных потоков. Так, к выгодам миграционных потоков для стран-реципиентов относят, например, возмещение недостатка рабочей силы и рост численности населения (вследствие убыли коренного населения), рост ВВП и производительности труда, рост потребительской активности, инновационную активность мигрантов. Издержки миграции для стран-реципиентов оцениваются с точки зрения давления на рынок труда и уровень заработной платы. Для стран-доноров, напротив, выгоды миграции оцениваются с точки зрения сумм денежных переводов, которые мигранты направляют в страныдоноры, и уменьшения давления на рынок труда вследствие избыточности трудовых ресурсов; издержки, наоборот, оцениваются с точки зрения оттока из страны высококвалифицированных специалистов (инженеры, врачи, ученые).

2. Институциональная. Сторонники указанной модели акцентируют внимание на взаимоотношениях между мигрантами и государственными органами, призванными осуществлять контроль за миграционными потоками. В рамках указанной модели возможны четыре различных подхода к миграции. Во-первых, это имперский подход, при котором преимущество в виде свободного въезда и преимущественного права на натурализацию имеют жители бывших колониальных владений. Во-вторых, это либеральный подход, основывающийся на индивидуальных правах въезжающих мигрантов и предполагающий вынесе-

1 World Migration Report 2018. URL: https://www.iom.int/wmr/world-migration-report-2018 (accessed 11.02.2019). 
ние решения о желательности пребывания мигранта исходя из его полезности для государства-реципиента и в соответствии с принятыми международными конвенциями. В-третьих, это этническая модель, в рамках которой в основу миграционной политики положено представление о самоценности этнической и культурной целостности принимающего сообщества. Вследствие этого преимуществом пользуются мигранты, имеющие то же этническое происхождение, что и население страны-реципиента. В-четвертых, это мультикультурная модель, предполагающая признание преимущества коллективных прав сообществ над индивидуальными правами и, как следствие, предоставляющая преимущественное право въезда и натурализации тем мигрантам, которые принадлежат этнически или культурно к сообществам, уже зарегистрированным на территории страны-реципиента.

3. Культуроцентрическая. Адепты данной модели указывают, что положения миграционной политики определяются той политической культурой, которая исторически сложилась на территории страны-реципиента. Существенное влияние на политическую культуру обращения с мигрантами имеет понимание природы национального сообщества. Так, например, если во Франции сложилась инклюзивная модель нации, предполагающая акцент на индивидуальных правах гражданина и требующая от гражданина проявления активности в утверждении себя в качестве члена национального сообщества (изучение французского языка, участие в политической жизни страны), то в Германии, наоборот, принадлежность к национальному сообществу определяется этническим происхождением гражданина. Соответственно, мигрант, имеющий немецкое происхождение, но не знающий немецкий язык и не имеющий представление о немецкой культуре, пользовался преимуществом по сравнению с мигрантом ненемецкого происхождения, в совершенстве знающим немецкий язык и выросшим в немецком культурном окружении.

4. Инструментальная. Сторонники указанной модели в качестве основы формирования миграционной политики государства рассматривают баланс притязаний различных политических сил, рассматривающих миграцию в качестве своего ресурса. Это могут быть политические партии, бизнес-структуры, этнические организации и организации, защищающие права мигрантов.

Указанные подходы выступают своеобразными чистыми случаями или, используя терминологию немецкого социолога М. Вебера, «идеальными типами» основ формирования миграционной политики, которые в реальном мире практически не встречаются. Соответственно, миграционная политика каждого конкретного государства является своеобразным смешением описанных выше моделей, обусловленным соотношением тенденций секьюритизации и либерализации миграционного процесса, которое данное конкретное государство полагает для себя возможным.

В данном случае под секьюритизацией понимается комплекс мер, реализуемых органами государственной власти, бизнес-структурами, общественными организациями в целях поддержания на территории страны-реципиента оптимального с их точки зрения уровня безопасности. Под уровнем безопасности в данном случае следует понимать степень воздействия миграции на социальные связи, обусловливающие устойчивость социума и его способность к саморазвитию.

Либерализация - это комплекс мер, реализуемых теми же субъектами, но направленный на поощрение миграции, обусловленное либо необходимостью развития экономики, либо выполнением гуманитарных обязательств в отношении мигрантов, либо иными обстоятельствами.

От соотношения указанных двух тенденций зависит тип миграционной 
политики государства - будет ли она носить ограничительный (эксклюзивный) или, напротив, поощрительный (инклюзивный) характер. Так, для эксклюзивной миграционной политики характерен акцент на секьюритизацию, следствием чего становится применение как формальных, так и неформальных механизмов, ограничивающих миграцию. Для инклюзивной модели, наоборот, характерно поощрение миграции с использованием тех же самых механизмов. К формальным механизмам следует отнести правовые, выступающие основой реализации миграционной политики, и организационные, реализующие миграционную политику от имени государства, институтов. К неформальным механизмам относятся различные общественные объединения, реализующие программы контроля за миграцией либо помощи мигрантам, а также культура восприятия мигрантов принимающим сообществом. Последняя может варьироваться от резкого неприятия мигрантов, что способствует доминированию тенденции к секьюритизации, до восприятия мигрантов в качестве необходимой и неотъемлемой части социума, что благоприятствует силам, ратующим за либерализацию миграционной политики.

С момента распада СССР Российская Федерация формировалась в качестве иммиграционной страны. По данным Росстата, с 1990 по 2017 г. на территорию России для постоянного местожительства въехали более 6,5 млн чел. Наибольший миграционный прирост наблюдался в 1994-1995 гг., когда на постоянное место жительства в страну въехали более 1,3 млн чел. Существенное сокращение наблюдалось в 2001-2004 гг., что, вероятно, было обусловлено принятием нового федерального закона «О гражданстве в Российской Федерации», установившего новые правила приобретения гражданства России ${ }^{1}$. Определенное восстановление численности прибывших на постоянное место жительства в РФ, согласно статистическим данным, началось только с 2007 г. Вероятно, это связано с реализацией государственной программы по оказанию содействия добровольному переселению в Российскую Федерацию соотечественников, проживающих за рубежом².

Еще более значительные миграционные потоки устремляются в РФ в рамках трудовой миграции. Ежегодно на территорию страны въезжают более 15-17 млн граждан иностранных государств, из них с целью осуществления трудовой деятельности - более 5 млн чел.

До нулевых годов в РФ практически отсутствовало законодательство, регулирующее положение иностранных граждан в России. Только в 2002 г. был принят федеральный закон «О правовом положении иностранных граждан в Российской Федерации», устанавливающий правила пребывания и проживания иностранных граждан на территории страны, а также осуществления ими трудовой деятельности ${ }^{3}$.

Указанный закон был призван установить правовые рамки взаимоотношений мигранта, с одной стороны, и органов государственной власти и российского общества - с другой. Этого, однако, оказалось недостаточно. Несмотря на принятые меры, в российском обществе наблюдалось нарастание ксенофобских

\footnotetext{
1 Федеральный закон «О гражданстве в Российской Федерации» от 31.05.2002 № 62-Ф3. Доступ: http://www.consultant.ru/document/cons_doc_LAW_36927/(проверено 01.03.2019).

2 Указ Президента РФ от 22.06.2006 N 637 (ред. от 15.03.2018) «О мерах по оказанию содействия добровольному переселению в Российскую Федерацию соотечественников, проживающих за рубежом» (вместе с «Государственной программой по оказанию содействия добровольному переселению в Российскую Федерацию соотечественников, проживающих за рубежом»). Доступ: http://www. consultant.ru/document/cons_doc_LAW_61111/(проверено 01.03.2019).

3 Федеральный закон «О правовом положении иностранных граждан в Российской Федерации» от 25.07.2002 № 115-Ф3. Доступ: http://www.consultant.ru/document/cons_doc_LAW_37868/ (проверено 01.03.2019).
} 
и антииммигрантских настроений, участились случаи насилия в отношении мигрантов. Антииммигрантские настроения тиражировались политиками и медиа. Следствием этого стал тренд роста секьюритизации миграционной политики в России. Так, Федеральная миграционная служба в 2002 г. была передана в ведение Министерства внутренних дел России, и, как следствие, акцент в миграционной политике был перенесен на борьбу с нелегальной миграцией. В 2008 г. был введен институт квотирования для трудовых мигрантов из безвизовых стран, одновременно были значительно повышены штрафы для работодателей, нанимавших «нелегальных» трудовых мигрантов. Указанный механизм квотирования, несмотря на свою громоздкость и неточность, позволил значительно повысить число мигрантов, покинувших «теневой» рынок труда. По разным оценкам, число легальных трудовых мигрантов выросло с 5-10\% в начале нулевых годов до примерно $30 \%$ - во второй половине нулевых.

Одновременно была либерализована система регистрации иностранных граждан. Вместо принятой громоздкой и неэффективной системы в 2007 г. был введен институт миграционного учета.

В начале 2010-х гг. тенденция на либерализацию миграционного законодательства нашла свое продолжение, с одной стороны, во ведении системы патентов для трудовых мигрантов, а с другой - введении института высококвалифицированных специалистов. Оба нововведения должны были способствовать дальнейшему выведению иностранных трудовых мигрантов с нелегального трудового рынка. ФМС России была выведена из ведения МВД России, превратившись в федеральную службу, находящуюся непосредственно в подчинении Правительства России. Одновременно данная служба инициировала работу по реализации программ адаптации и интеграции иностранных граждан.

Однако с 2013 г. тенденция либерализации начинает сворачиваться. Инициатива по усилению тренда секьюритизации принадлежала президенту России В.В. Путину. В рамках послания Федеральному собранию РФ он указал на отсутствие должного порядка в сфере трудовой миграции, что способствует росту национальных конфликтов и криминализации ситуации в стране. Соответственно, были приняты меры, направленные на снижение уровня иностранной миграции в стране:

1) принято решение о введении обязательной сдачи для трудовых мигрантов экзамена по русскому языку (с 2013 г.), а также по истории России и основам законодательства РФ (с 2015 г.);

2) введены правила о депортации и выдворении мигрантов с территории России с запрещением им обратного въезда в течение 3 или 5 лет в зависимости от степени тяжести совершенного правонарушения;

3) расширено действие патента на право осуществления трудовой деятельности для мигранта на работу на юридических лиц. Однако условием получения патента служит прохождение медицинской комиссии в аккредитованном центре, а также успешная сдача экзамена по русскому языку, истории России и основам законодательства РФ.

В 2015 г. ФМС России потеряла статус федеральной службы и была реорганизована в Главное управление по миграции МВД России.

Принятие в 2018 г. Концепции миграционной политики Российской Федерации на 2019-2025 гг. подтвердило курс на усиление тренда секьюритизации в миграционной политике страны. Так, если в редакции Концепции 2012 г. в качестве целей были заявлены стабилизация и увеличение численности постоянного населения РФ, а также содействие обеспечению потребности экономики РФ в рабочей силе, модернизации, инновационном развитии и повышении конкурентоспособности ее отраслей, то в новой редакции 2018 г. 
единственной целью является «создание миграционной ситуации, которая способствует решению задач в сфере социально-экономического, пространственного и демографического развития страны, повышения качества жизни ее населения, обеспечения безопасности государства, защиты национального рынка труда, поддержания межнационального и межрелигиозного мира и согласия в российском обществе, а также в сфере защиты и сохранения русской культуры, русского языка и историко-культурного наследия народов России, составляющих основу ее культурного (цивилизационного) кода» 1.

Принимая во внимание высокий уровень мигрантофобии населения России, указанный тренд выглядит оправданным ${ }^{2}$. Однако не стоит забывать, что общественное мнение в значительной степени зависит от средств массовой информации, деятельность которых определяется в первую очередь государственной политикой в указанной области.

Статья подготовлена по результатам исследований, выполненныхзасчет бюджетныхсредств погосударственному заданию Финуниверситету 2019 г.

ARSHIN Konstantin Valer'evich, Cand.Sci. (Philos.), Financial University under the Government of the Russian Federation (49 Leningradsky Ave, Moscow, GSP-3, Russia, 125993; kosta-10@yandex.ru)

\section{DIALECTICS OF SECURITIZATION AND LIBERALIZATION IN THE MIGRATION POLICY OF RUSSIA}

Abstract. The article discusses the mutual influence of two trends in the migration policy of the Russian Federation - the trends of securitization and liberalization. The author traces how these trends are reflected in management decisions in the migration sphere of the country and regulatory legal acts. According to the results of the analysis, the author formulates a conclusion that the trend of securitization dominates in the current migration policy of the country.

Keywords: securitization, liberalization, migration, labor migration, migration model

1 Указ «О Концепции государственной миграционной политики Российской Федерации на 20192025 годы». - Президент России. Официальный сайт. 31 октября 2018 г. Доступ: http://kremlin.ru/events/ president/news/58986 (проверено 11.02.2019).

2 Отношение к мигрантам в России ухудшается. - Левада-Центр. 27 апреля 2017 г. Доступ: https:// www.vedomosti.ru/politics/articles/2017/04/28/687871-otnoshenie-migrantam-uhudshaetsya (проверено 11.02.2019). 